\title{
STUDI TENTANG DIGITALISASI ONDEL-ONDEL BETAWI MELALUI TEKNOLOGI 3-D ANIMASI
}

\author{
Ferric Limano \\ Program Studi Doktor Ilmu Seni Rupa dan Desain \\ Fakultas Seni Rupa dan Desain, Institut Teknologi Bandung \\ Jalan Ganesha 10 Bandung \\ No. Tlp.:+628194851656, E-mail: ferric.limano@gmail.com \\ Yasraf Amir Piliang \\ Fakultas Seni Rupa dan Desain, Institut Teknologi Bandung \\ Jalan Ganesha 10 Bandung \\ Irma Damajanti \\ Fakultas Seni Rupa dan Desain, Institut Teknologi Bandung \\ Jalan Ganesha 10 Bandung \\ Rismiyati E. Koesma \\ Fakultas Seni Rupa dan Desain, Institut Teknologi Bandung \\ Jalan Ganesha 10 Bandung
}

\begin{abstract}
ABSTRAK
Indonesia kaya akan warisan budaya. Salah satu ragam warisan budaya yang terdapat di Indonesia adalah seni pertunjukan tradisional. Seni pertunjukan ini melibatkan peran individu atau kelompok di dalam satu waktu dan ruang. Kesenian tradisional merupakan identitas kultural masyarakat lokal. Hal ini merupakan wajib menjadi pertahanan identitas masyarakat tersebut agar tidak kehilangan jati diri dalam masyarakat berbudaya. Terlebih lagi arus globalisasi yang membuat budaya tradisional mulai kurang diapresiasi, dibandingkan budaya global. Ondel-ondel merupakan salah satu seni pertunjukan tradisional, yang memiliki nilai ikonik dan komersial. Apresiasi terhadap ondel-ondel pun mulai pudar. Melalui penelitian ini dibahas bagaimana produksi animasi $3 D$ digital untuk ondel-Ondel Betawi. Data didapatkan melalui eksperimental visual dan gerak, kemudian data dianalisis dan dideskripsikan. Hasil dari penelitian ini adalah menjadi kajian prinsip gerak terhadap kesenian pertunjukan tradisional sehingga masyarakat dapat menikmati kesenian tradisional Indonesia dalam media baru.
\end{abstract}

Kata kunci: animasi, digital, ondel-ondel, produksi

\section{ABSTRACT}

Study on Digitalization Ondel-ondel Betawi through 3D Animation Technology. Indonesia is rich in cultural heritage, one of the various cultural heritages found in Indonesia is traditional performing arts. This performing art involves the role of individuals or groups in one time and space. Traditional art is the cultural identity of the local community. This is an obligation to defend the identity of the community, so as not to lose their identity in a cultured society. Moreover, the flow of globalization has made traditional culture less appreciated, compared to global culture. Ondel-ondel is one of the traditional performing arts, has iconic and commercial value. Appreciation for Ondel-ondel is starting to fade, through this research how to make a digital 3D animation production for Ondel-ondel Betawi. Data obtained through visual and motion experimental, then the data will be analyzed and described. The result of this research is to study the principles of movement towards traditional performing arts, so that people can enjoy Indonesian traditional arts in new media

Keywords: animation, digital, ondel-ondel, production 


\section{PENDAHULUAN}

Manusia adalah satu-satunya makhluk yang memiliki kebudayaan. Kebudayaan menurut Koentjaraningrat dapat didefinisikan sebagai keseluruhan sistem gagasan, Tindakan, dan hasil karya manusia dalam rangka kehidupan masyarakat yang dijadikan milik diri manusia dengan belajar. Seturut dengan pengertian ini yang menjadi fokus utama adalah hasil karya dari kebudayaan itu sendiri (Koentjaraningrat, 2007).

Kebudayaan secara umum dapat dibagi menjadi dua, yaitu modern dan tradisional. Kebudayaan modern adalah budaya yang dihasilkan karena adanya arus globalisasi, sedangkan kebudayaan tradisional adalah hasil dari warisan leluhur yang diberikan secara turun-temurun. Warisan budaya ini terdiri dari seni pertunjukan, alat musik daerah, senjata, bahasa lokal, pakaian, aristektur, dan lainnya yang diwariskan secara turun-temurun. Indonesia merupakan negara yang memiliki kekayaan kebudayaan tradisional karena hampir di setiap daerah memiliki hasil budaya yang terekspresi oleh masyarakat lokalnya. Warisan budaya yang diberikan selalu mewakili pengetahuan, gagasan, keyakinan, kepercayaan, bahkan nilai dan norma suatu masyarakat (Andri R.M., 2016).

Di dalam kebudayaan tradisional terdapat seni pertunjukan tradisional, yang merupakan karya seni yang melibatkan individu ataupun kelompok dalam lingkup waktu dan tempat. Tujuannya adalah mempertunjukkan gerakan, objek, ataupun ritual kepada penonton sehingga ada interaksi dan apresiasi di dalamnya. Beberapa seni pertunjukan menampilkan boneka sebagai objek yang dipertunjukkan kepada penonton. Beberapa contoh pertunjukan boneka tradisional yang terkenal di dunia antara lain marionette (Amerika), bunraku (Jepang), potehi (China), tógalugómbeaț̣a (India), wayang kulit (Indonesia) (Cohen, 2014).

Selain wayang kulit sebagai seni pertunjukan tradisional yang menggunakan boneka, masih terdapat banyak ragam seni tradisonal Indonesia yang menggunakan objek boneka. Secara sederhana pengertian boneka adalah gambaran dari sesuatu (manusia, hewan, dan lain sebagainya) yang dapat digerakkan dari dalam ataupun luar. Ondel-ondel adalah salah satu seni pertunjukan tradisional yang terdapat di Indonesia. Ondelondel merupakan boneka raksasa dengan tinggi 2,5 meter dan lebar sekitar 80 centimeter yang dibuat dengan anyaman bambu, topeng pada bagian wajah dengan ijuk pada bagian rambut. Ondel-ondel biasa tampil dalam pertunjukan untuk memeriahkan acara seperti pernikahan orang Betawi ataupun acara sunatan. Seni pertunjukan ini menampilkan ondelondel pria dan perempuan berjalan, menari, dan berputar dengan musik khas Betawi. Ondel-ondel dahulu dikenal dengan sebuatan "barongan" dan pembuatannya perlu menggunakan ritual seperti sajen serta bubur merah putih, rujak-rujakan tujuh rupa, bunga tujuh macam, dan kemenyan. Setelah selesai dibuat, ondel-ondel diberikan sesajen dan dibasuh dengan asap kemenyan dan dimantrai (Chienita, Susanto, \& Winduwati, 2019).

Kesenian tradisional merupakan identitas kultural masyarakat lokal. Hal ini merupakan wajib menjadi pertahanan identitas masyarakat tersebut agar tidak kehilangan jati diri dalam masyarakat berbudaya. Terlebih lagi arus globalisasi membuat budaya tradisional mulai kurang diapresiasi, dibandingkan budaya global. Secara sederhana dapat dipahami dengan maraknya anak-anak muda menyukai tarian K-Pop dibandingkan dengan tarian tradisional. Hal ini juga dipengaruhi dengan video clip yang menarik bagi generasi muda sehingga menjadi satu ketertarikan yang wajar dalam merespons media tersebut. Internet dengan banyak platform aplikasi juga menjadi salah satu faktor tidak adanya lagi batasan bagi budaya global. Oleh sebab itu, perlunya strategi kebudayaan Indonesia, dengan menggunakan basis multimedia di dalam pengembangannya. Hal ini berarti memanfaatkan teknologi untuk mengembangkan kesenian tradisional ke dalam media baru sehingga akan muncul apresiasi baru dalam masyarakat Indonesia (Irianto, 2017). 
Dalam penelitian ini penulis membatasi objek kesenian tradisional yang akan digunakan sebagai kajian, yaitu ondel-ondel Betawi. Beberapa alasan menggunakan ondel-ondel Betawi sebagai objek dalam penelitian ini antara lain: (1) Ondelondel ditetapkan sebagai ikon kota Jakarta pada Peraturan Gubernur No. 11 Tahun 2017 (Patent No. 11, 2017); (2) Ondel-ondel mulai kehilangan apresiasi dan nilai makna yang tepat dalam masyarakat. Sekarang menjadi satu objek yang digunakan sebagai alat ngamen (Chienita et al., 2019); (3) Ondel-ondel memiliki variabel komunikasi visual yang baik dan memiliki nilai komersial di dalam pengolahan ke berbagai media (Purbasari, Marianto, \& Burhan, 2019).

Tantangan globalisasi tidak cukup membuat kesenian tradisional perlahan mengalami merosotnya apresiasi masyarakat. Industri 4.0 di dalam global membuat teknologi menjadi salah satu komponen penting di dalam kehidupan masyarakat. Fenomena baru di dalam industri ini membuat segala sesuatu menjadi serba digital (Tay, Lee, Hamid, \& Ahmad, 2018.Pada era ini juga setiap produk kultural berhadapan langsung dengan generasi digital. Generasi yang sangat dekat dengan teknologi, sangat mudah menerima semua informasi secara digital (Harari, 2018). Bahkan saat ini pandangan masyarakat memiliki fokus utama pada hal yang berbasis digital dan teknologi, dibandingkan dengan sesuatu yang bersifat konvensional (Haqqu, 2020). Karena itu, ada satu urgensi terhadap kebudayaan yang bersifat konvensional pun, perlu menjadi pemikiran bagi setiap masyarakat Indonesia. Oleh sebab itu, setiap kesenian tradisional perlu ada pemikiran untuk dilakukan pengembangan ke dalam bentuk digital. Penelitian ini akan mencoba media 3D animasi sebagai percobaan penerapan tersebut.

Dapat ditarik pertanyaan dalam penelitian ini adalah bagaimana membuat ondel-ondel Betawi secara digital dengan pendekatan ilmu komunikasi visual animasi. Secara visual ondel-ondel akan dipindahkan ke dalam model 3D dengan bantuan software $3 D$ editor. Kemudian di dalam geraknya penerapan 12 prinsip animasi akan diterapkan pada gerak ondel-ondel Betawi (Tri Widadijo, 2020.

Tujuan penelitian ini adalah melakukan proses produksi animasi tiga dimensi dari ondelondel Betawi. Terutama dalam pola geraknya yang sesuai dengan ilmu komunikasi visual animasi yang tepat sehingga muncul rekomendasi gerakan baru pada ondel-ondel Betawi.

Hasil dari penelitian ini adalah menjadi kajian prinsip gerak terhadap kesenian pertunjukan tradisional. Dengan demikian, masyarakat dapat menikmati kesenian tradisional Indonesia dalam media yang baru.

\section{METODE PENELITIAN}

Metode penelitian yang digunakan secara kualitatif akan dilakukan ke dalam dua skema pembuatan. Dua skema pembuatan tersebut adalah secara visual dan juga gerak.

Pembangunan ondel-ondel Betawi digital ini memiliki pendekatan psikologis, yaitu teori Uncanny Valley (Mori, MacDorman, \& Kageki, 2012). Penggunaan teori ini dikarenakan ondelondel Betawi dapat dikategorikan ke dalam kesenian tradisional boneka yang sama dengan eksperimental yang dilakukan Mori, yaitu Bunraku Puppet. Variabel yang terdapat dalam Uncanny Valley terdiri dari visual dan gerak, yang dapat diterapkan ke dalam eksperimental visual dan gerak pada ondel-ondel Betawi.

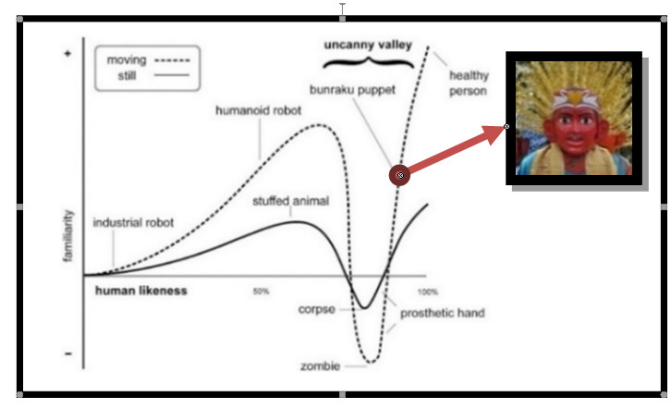

Gambar 1 Posisi ondel-ondel pada diagram Uncanny Valley

Eksperimental visual 3D Model ondelondel akan dilakukan dengan cara mengubah gaya visual dari ondel-ondel 3D. Hal ini seperti 
diungkapkan dalam penelitian sebelumnya, gaya visual dengan bentuk ikonik/pixar style, lebih menarik dibandingkan visual style realistik (Bouwer \& Human, 2017. Karena itu, sasaran visual ondelondel Betawi yang menimbulkan ketertarikan individu dapat digambarkan sebagai berikut.

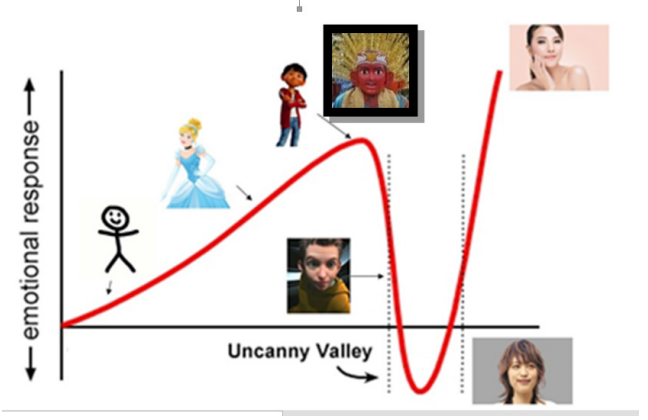

Gambar 2 Sasaran visual ondel-ondel

Betawi dalam media 3D

Selanjutnya pendekatan gerak pada ondelondel Betawi untuk menyeimbangkan diagram Uncanny valley adalah sebagai berikut. Jika visual tidak realistik, tidak akan dituntut gerakan yang realistik. Selama berhubungan dengan gerak ikonik, 12 prinsip animasi adalah yang paling sesuai terhadap karakter ikonik.

Observasi mandiri yang dilakukan peneliti terhadap gerak ondel-ondel Betawi dapat dideskripsikan dalam tabel 1 .

Tabel 1 Gerakan ondel-ondel Betawi Riil

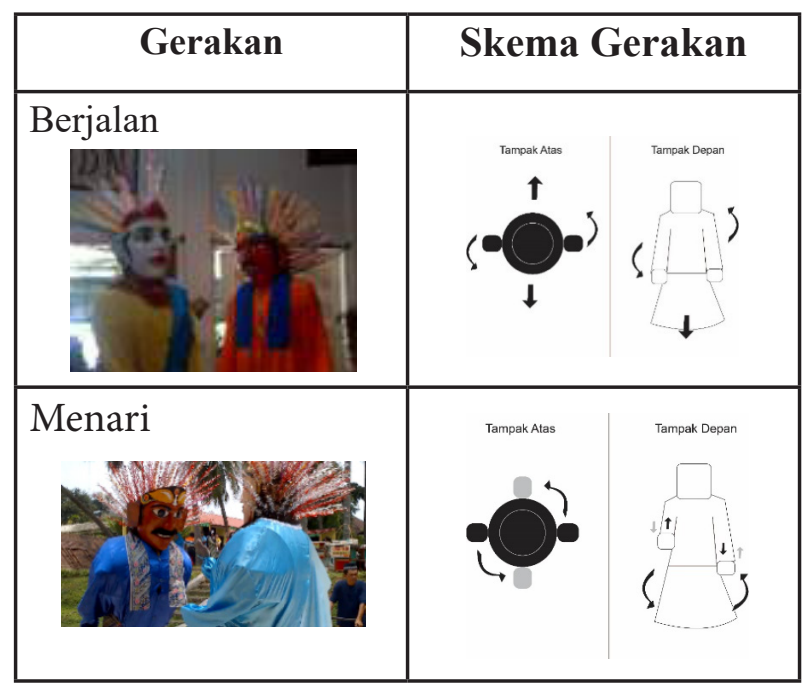

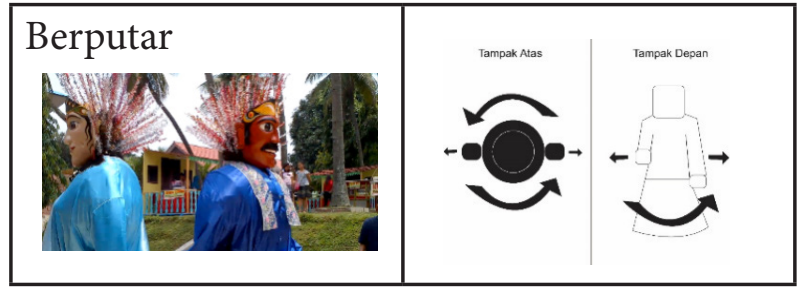

Pada gerakan ondel-ondel Betawi riil, dilakukan pengambilan sampel bagaimana respons individu terhadap gerakan ondel-ondel Betawi. Respons sampel sebanyak 92 individu, berikut ini adalah hasilnya. 58,7\% mengungkapkan gerakan ondel-ondel biasa saja, menandakan tidak ada emotional engagement terhadap objek ini. $31,5 \%$ mengatakan aneh/menakutkan, sisanya menganggap gerakan ondel-ondel menarik. Dapat disimpulkan bahwa ketertarikan individu terhadap gerakan ondel-ondel Betawi sangat rendah.

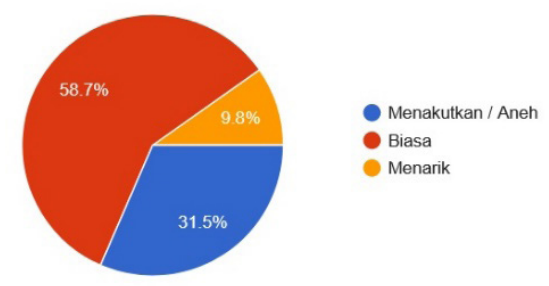

Gambar 2 Diagram survei terhadap gerak ondel-ondel Betawi riil

Karena itu, akan dilakukan skema gerak seturut dengan 12 prinsip animasi pada skema gerakan ondel-ondel Betawi, dalam sampel terdapat berjalan, menari, dan berputar. Pada penelitian ini diputuskan menggunakan skema gerak berjalan dikarenakan merupakan gerakan basic pada gerakan tubuh karakter (Williams, 2012).

Di dalam gerakan berjalan ondel-ondel tersebut akan dilakukan pembagian 12 prinsip animasi, yang memang tidak bisa dipisahkan satu dengan yang lain. Akan tetapi, setiap prinsip dapat dilakukan identifikasi dominan dalam gerakan karakter ondel-ondel Betawi. 


\section{PEMBAHASAN}

Data visual awal dari 3D ondel-ondel Betawi diambil dari data sekunder. Data sekunder dibuat oleh Ajitec pada web 3dwarehouse.sktechup (Ajitec, 2018). Kemudian data 3D tersebut akan dilakukan revisualisai dengan teori Uncanny Valley, dengan sasaran gaya visual Pixar Animation Studio (Pixar, 2021).

Beberapa metode dilakukan hingga proses revisualisasi sesuai dengan sasaran dari diagram Uncanny Valley. Tahapan pertama adalah perbaikan data sekunder, dengan mengurangi jumlah poligonal pada 3D dan perbaikan poligonal normal pada 3D model. Topologi awal sebanyak 940.000 poligonal menjadi 40.000 poligonal. Hal ini dilakukan pengurangan dari kembang kelapa ondel-ondel dan bagian cukin pada ondel-ondel laki-laki.

Kemudian setelah data selesai diperbaiki, dilanjutkan pada tahap revisualisasi. Hal yang signifikan dilakukan perubahan pada tekstur, mata, dan kulit ondel-ondel 3D. Kemudian dilakukan deformasi terhadap ondel-ondel 3D hingga sesuai dengan gaya ikonik dari pixar animation studio. Berikut ini adalah gambaran proses dalam perbaikan visual ondel-ondel Betawi secara digital. Selanjutnya diperlukan perbaikan topologi yang sesuai untuk dilakukan proses rig \& skinning dalam 3D sehingga dapat dilakukan animasi pada karakter ondel-ondel Betawi.

Tabel 2 Proses Revisualisasi

3D Ondel-ondel Betawi

\begin{tabular}{|c|c|}
\hline Gambar Proses & Keterangan \\
\hline & $\begin{array}{c}\text { Export Import file } \\
\text { dari sketchup, ke } \\
\text { 3DSMax }\end{array}$ \\
\hline & $\begin{array}{c}\text { Pengurangan } \\
\text { poligonal pada } \\
\text { kembang kelapa } \\
\text { dan cukin sehingga } \\
\text { efisien dalam } \\
\text { kapasitas data }\end{array}$ \\
\hline
\end{tabular}

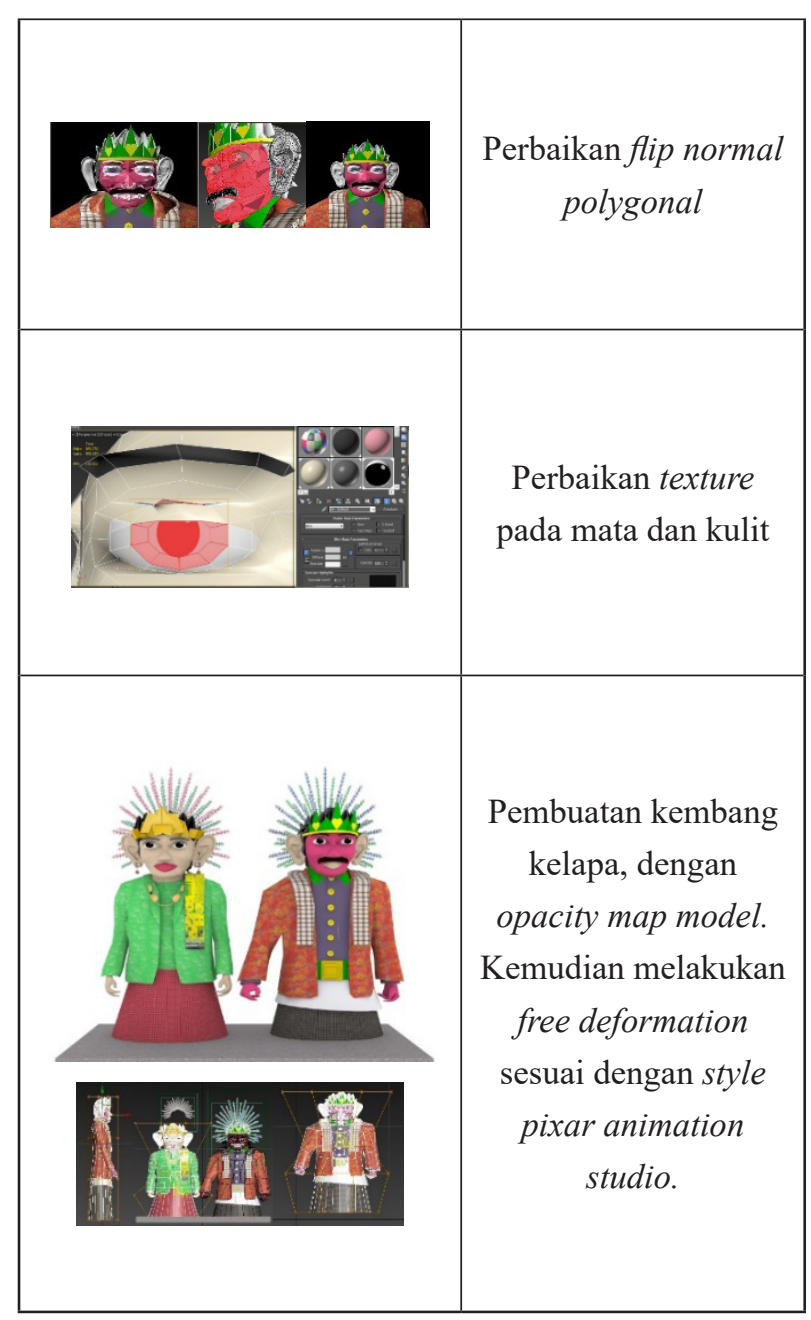

Berikut ini adalah perbandingan visual awal yang didapatkan secara online, kemudian yang telah disesuaikan dengan sasaran gaya visual ikonik.

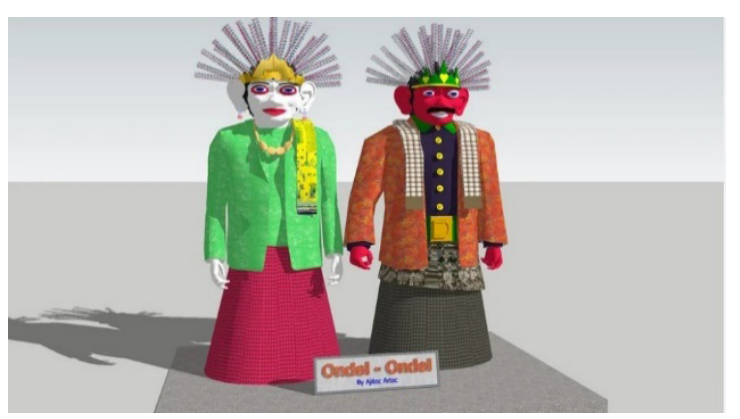

Gambar 3 Data awal ondel-ondel 3D (gaya realistik) 


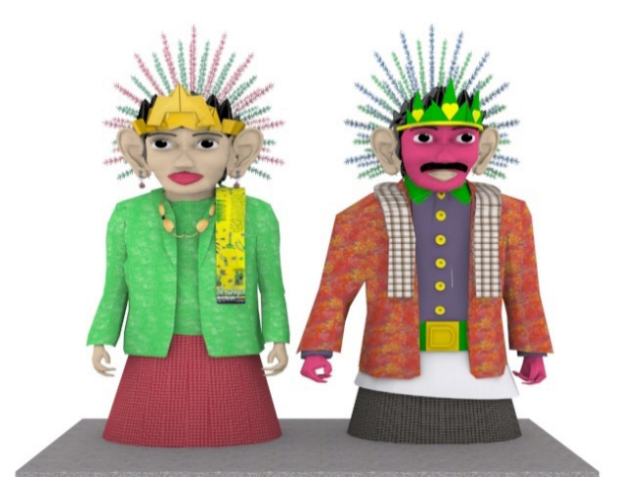

Gambar 4 Data hasil revisualisasi

Ondel-ondel 3D (gaya ikonik)

Gaya visual tiga dimensi yang realistik kadang membuat penonton memiliki satu perasaan bahwa karakter tersebut seperti boneka yang mati (Pollick, 2010). Hal ini disebabkan oleh perasaan psikoanalisis dalam individu, ketika adanya batasan fantasi dan kenyataan menjadi kabur. Kondisi ini muncul ketika individu berhadapan dengan visual yang terdapat dalam realitas, tetapi tidak sesuai dengan memorinya (Freud, 2003). Personafikasi ondel-ondel digital awal terlihat menyerupai wujud manusia, tetapi dengan tampilan yang berbeda sehingga dalam rekaman psikoanalisis individu, ada perasaan yang salah ketika melihat wujud ondel-ondel digital ini, baik secara proporsi, warna, maupun bentuknya. Dikarenakan rekaman memori ketika melihat ondel-ondel ini adalah manusia, di dalam inderawi terdapat perbedaan orientasi yang menyebabkan ondel-ondel digital awal mengalami Uncanny (Jentsch, 1906.

Selanjutnya masuk ke dalam pembahasan gerak pada ondel-ondel Betawi 3D. Setelah menyelesaikan 3D model, dilakukan proses rig \& skinning pada ondel-ondel Betawi. Pada proses ini penulis menggunakan sistem rigging bipedal bone skeleton, yang disebut biped. Tools biped sangat umum dan sering digunakan dalam produksi animasi karena prosesnya yang sederhana untuk digunakan. Biped telah memiliki kesesuaian proporsi dengan karakter yang akan diberikan rig bone, hanya saja perlu dilakukan penyesuaian lagi agar tepat dengan anatomi karakter (Arshad, Yoon, Manaf, \& Ghazali, 2019). Pada proses pembuatan rig ondel-

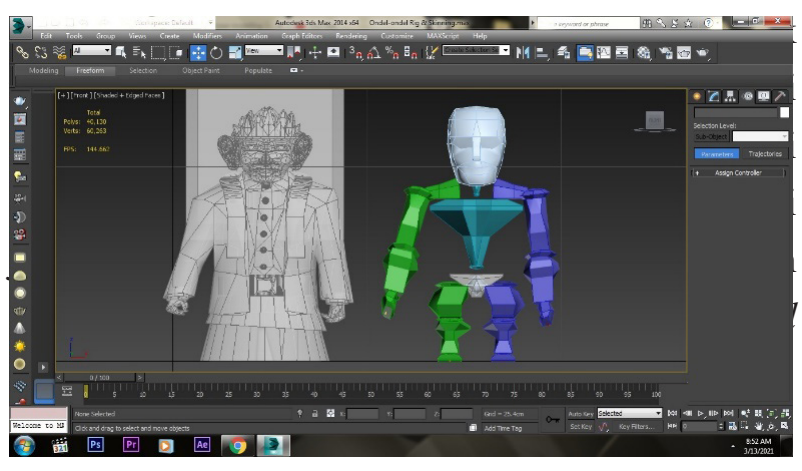

Gambar 5 Struktur biped tools pada ondel-ondel Betawi digital

Struktur biped yang sudah selesai akan dilakukan penyesuaian dengan skala dari polygonal meshes 3D ondel-ondel. Maka, selanjutnya dilakukan proses skinning. Proses skinning dalam penelitian ini adalah penyatuan bone (biped tools) dengan mesh 3D ondel-ondel. Hal yang terpenting dalam proses ini adalah pengaturan weight, yaitu kemampuan mesh melekat dengan bone. Kadang kali perlu dilakukan perbaikan berdasarkan point vertex yang terpengaruh bone yang tidak diinginkan. Variabel weight pengaruh bone pada mesh, terdiri dari angka 0 sampai dengan 1 . Nol berarti tidak memiliki pengaruh dari bone tersebut, angka satu memiliki pengaruh yang kuat terhadap bone tersebut. Jika pembagian weight sudah tepat terhadap bone, mesh akan sesuai mengikuti pergerakan bone nantinya (Xu, Chen, Xie, \& Wu, 2011)

Tabel 3 Proses Skinning

\begin{tabular}{|c|c|c|}
\hline No. & Proses & Gambar \\
\hline 1 & Penyesuaian & \\
& biped tool \\
dengan 3D & \\
& ondel-ondel. \\
& Menggunakan \\
& modifier \\
physique & & \\
\end{tabular}




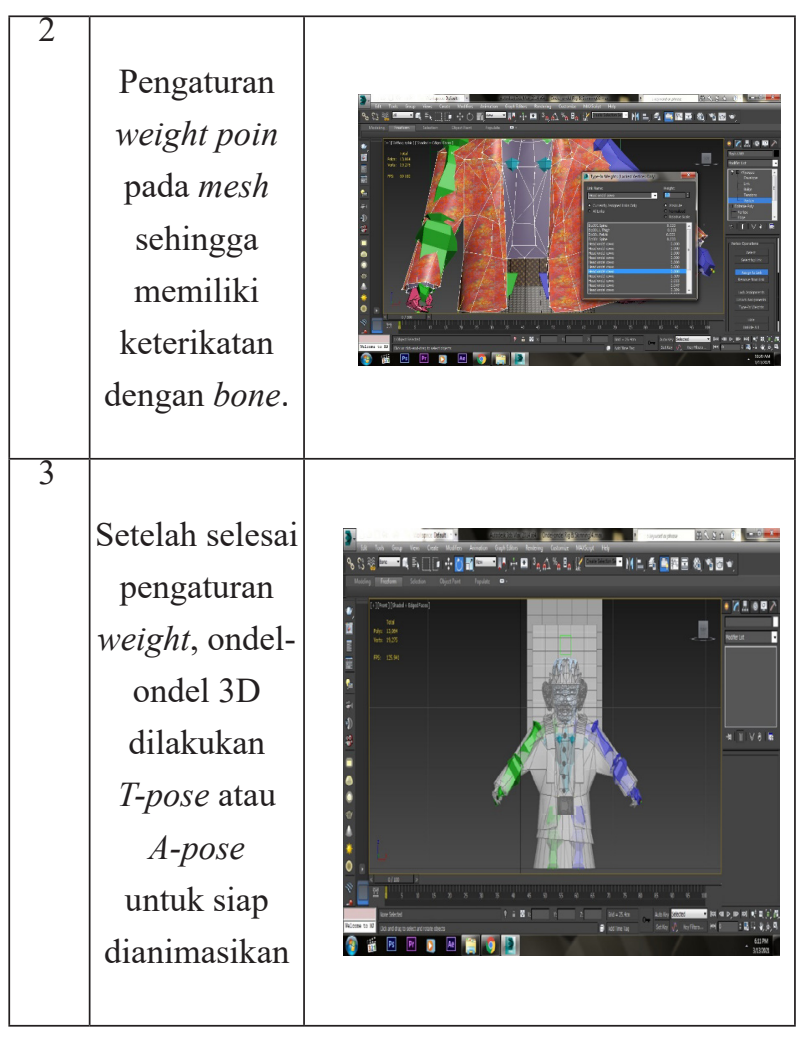

Berikut ini adalah proses skinning. Gerakan pada ondel-ondel yang dipilih, untuk mendemonstrasikan simulasi animasi adalah berjalan. Berjalan dipilih karena dianggap gerakan dasar dalam karakter dan dianggap paling natural. Bahkan karakter apa saja memiliki gerakan berjalan (Bai, Kaufman, Liu, \& Popović, 2016

Pada data awal gerakan berjalan ondelondel riil sangat kaku dan menghasilkan perasaan aneh bagi individu. Gerakan yang terdapat dalam ondel-ondel riil bersifat statis. Gerakan ondelondel digital dibuat berdasarkan penerapan 12 prins animasi, video gerakan berjalan, dan skema gerakan walk cycle oleh Richard Williams.

Pada tahap awal, dilakukan pose gerakan dengan membuat keyframe berdasarkan urutan metode walk cycle berikut; contact, down, pass, up, contact (pada kaki kanan dan kiri). Selain itu, dilakukan observasi berdasarkan referensi video berjalan laki-laki (Endless Reference, 2011) dikarenakan ondel-ondel yang digerakkan adalah karakter laki-laki. Proses pembuatan keyframe dilakukan mulai dari contact kaki kiri kemudian kanan, dan kembali lagi ke kiri. Kemudian baru dibuat pose di antara contact, yaitu down, pass, dan up.

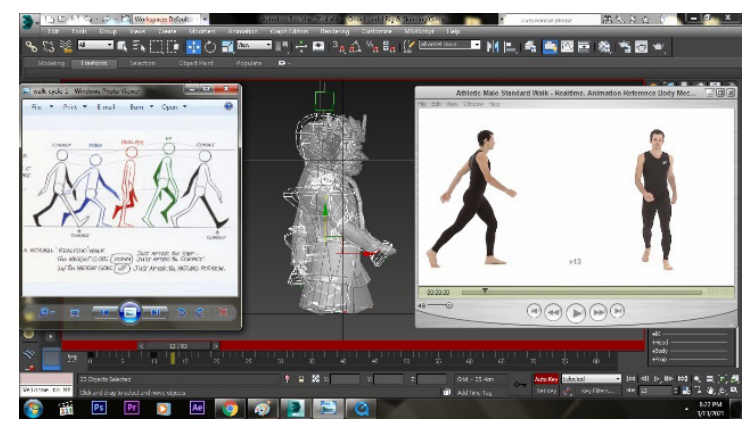

Gambar 6 Proses pembuatan pose dasar walk cycle

Dengan diselesaikannya proses keypose pada karakter ondel-ondel 3D, selanjutnya menerapkan prinsip dalam animasi pada gerakan ondel-ondel 3D. Tujuan 12 prinsip animasi ini adalah membuat karakter tersebut dapat diterima atau dipercaya oleh individu, bahkan memberikan ilusi dari kehidupan itu sendiri. Berikut ini yang disebut 12 prinsip animasi: Squash and Stretch, Anticipation, Exaggeration, Arcs, Overlapping Action \& Follow Through, Secondary Action, Timing \& Spacing, Slow in \& Slow out, Staging, Appeal, Solid Drawing, Straight ahead - Pose to Pose Technique (Sultana, Meissner, \& Peng, 2013).

Berikut ini adalah proses penerapan 12 prinsip animasi pada ondel-ondel 3D yang telah dibuat. Sebagai catatan bahwa 12 prinsip ini tidak bisa dipisahkan satu dengan yang lainnya, tetapi bisa dideskripsikan berdasarkan sampel data animasi ondel-ondel sebagai yang dominan.

Squash and Stretch, prinsip ini membicarakan kondisi perubahan bentuk karakter dari posisi terendah ke posisi tertinggi. Prinsip ini terlihat pada gerakan ondel-ondel ketika berada dalam posisi down (squash) dan up (stretch). 

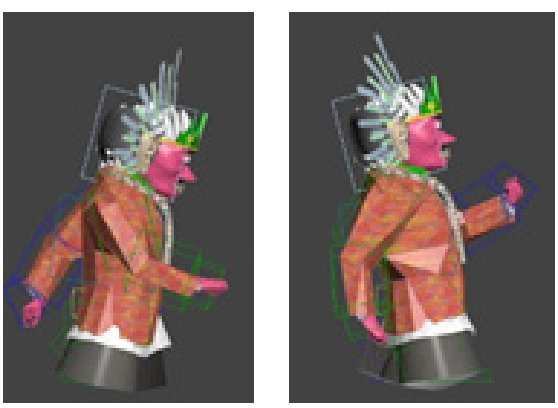

Gambar 7 Squash and Stretch

Anticipation, persiapan sebelum melakukan gerakan. Pada sampel gerakan ondel-ondel 3D ini, terlihat ketika posisi pass pada Ondel-ondel Betawi. Posisi ini adalah satuopersiapan sebelum ondelondel mengubah kaki dan tangannya.

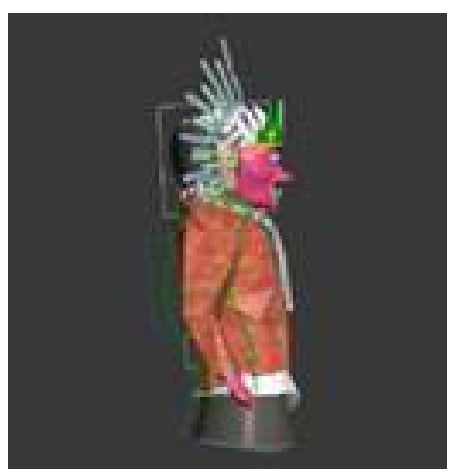

Gambar 8 Anticipation

Exageration, adalah penambahan gerakan yang melebih-lebihkan terhadap karakter. Dalam hal ini terlihat pada gerakan kepala ondel-ondel yang di gerakan turun naik yang dilebih-lebihkan, ketika up pose kepala didongakkan secara extreme. Biasa dominan gerakan ini bersamaan dengan gerakan squash and stretch.

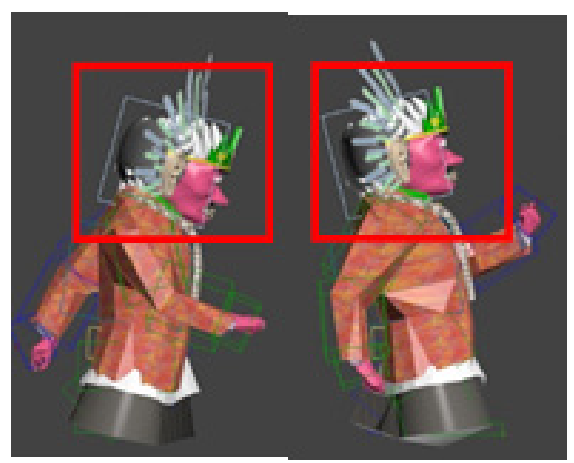

Gambar 9 Exageration
Arcs, prinsip ini memberikan gerakan yang natural dan organik dengan melihat pergerakan melingkar pada sumbu pergerakan bone pada karakter. Prinsip ini diterapkan paling utama pada gerakan turun naiknya ondel-ondel, jika dibuat garis akan terlihat seperti berikut.

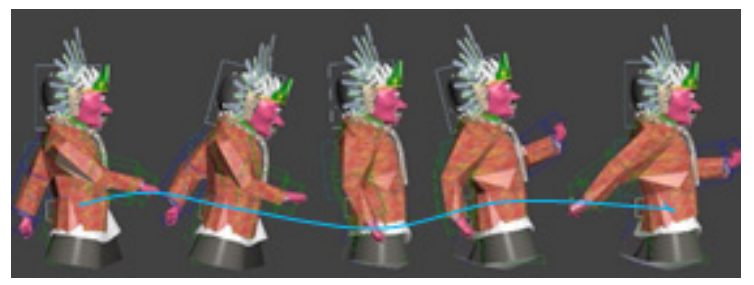

Gambar 10 Arcs

Overlapping \& Followthrough, gerakan yang mengikuti dan melampaui. Gerakan ini sangat terlihat pada gerak tangan ondel-ondel ketika bergerak ke depan dan ke belakang. Kembang kelapa pada kepala ondel-ondel 3D juga mengalami gerakan yang mengikuti dan melampaui.

Secondary Action, gerakan tambahan yang ditambahkan pada gerakan utama. Dalam hal ini terlihat pada gerakan kembang kelapa yang bergerak untuk ditambahkan pada gerakan utama. Wajah ondel-ondel juga bisa saja dibuat bergerak untuk menjadi gerakan tambahan pada gerak berjalan ondel-ondel.

Timing \& Spacing, timing adalah waktu yang ditentukan dalam gerakan yang diinginkan. Dalam hal ini dalam menentukan pose yang terdapat dalam ondel-ondel. Adapun spacing adalah jumlah gambar dalam waktu animasi. Hal ini juga berkaitan nantinya dengan percepatan dan perlambatan gerakan.

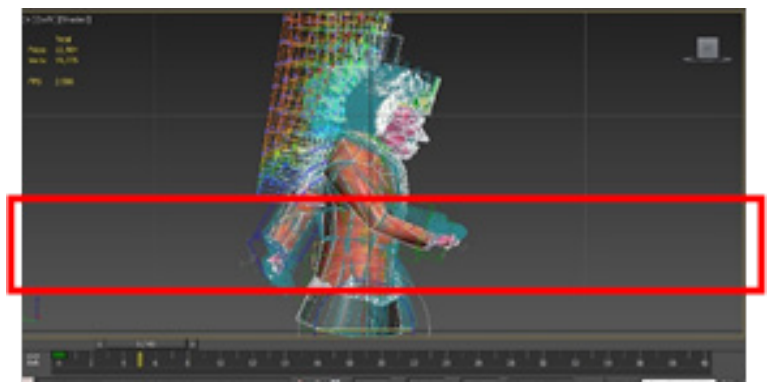

Gambar 11 Timing \& Spacing 
Slow in \& Slow out (ease in \& ease out), percepatan dan perlambatan pada gerakan. Dalam proses pembuatan gerakan ondel-ondel ini dilakukan proses pengaturan pada curva biped.

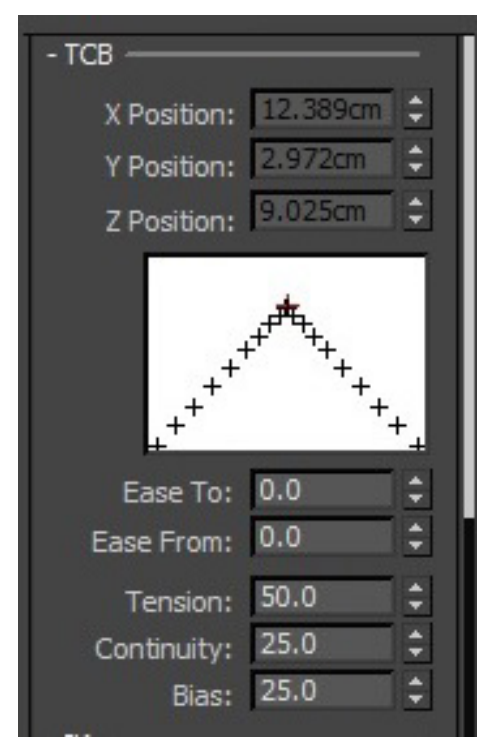

Gambar 12 Tension, Continuity, Bias editor

Staging, berbicara kepada lingkungan karakter dalam film animasi. Komposisi emphasis dari keseluruhan film, dalam bagian ini belum terlihat staging yang berarti dalam gerakan ondelondel. Karena animasi dilakukan untuk demo gerakan berjalan, jika ada kompleksitas yang akan diberikan ke penonton barulah akan dibuat setting latarnya.

Appeal, berkaitan dengan gaya visual dari ondel-ondel 3D. Dalam hal ini ondel-ondel telah dilakukan deformasi seturut dengan pixar karakter.

Solid Drawing, berbicara kepada kemampuan fundamental dari animator. Terdiri dari gambar pose anatomi, kepekaan dalam mempelajari observasi sehingga visual gerak terlihat solid bagi penonton.

Straight ahead - Pose to Pose Technique, dalam hal ini adalah teknik dalam membuat frame gambar dalam animasi. Pose to pose digunakan untuk mendapatkan pose utama dari gerakan ondelondel (set key). Setelah itu, dilakukan perbaikan detail penambahan prinsip animasi menggunakan teknik straight ahead (auto key).
Terdapat dua kategori dalam kebudayaan Indonesia, yaitu budaya benda dan nonbenda (Wikayanto, Grahita, \& Darmawan, 2019).Dengan pembuatan animasi digital terhadap kebudayaan benda akan menjadi satu media baru untuk memperkenalkan kebudayaan Indonesia tersebut dengan cara yang menarik kepada masyarakat global. Contoh kasus penerapan ondel-ondel ke dalam 3D animasi bisa menjadi strategi yang tepat, tetapi perlu proses produksi yang sesuai untuk meningkatkan daya tarik penonton/individu.

Hasil dari pernelitian ini dideskripsikan secara singkat sebagai berikut. Ondel-ondel Betawi secara digital merupakan percobaan terhadap objek budaya Indonesia dalam media yang baru. Dengan tujuan menghasilkan daya tarik yang berbeda dengan objek budaya ondel-ondel secara langsung. Hasil percobaan tersebut berupa rekonstruksi visual dan gerak. Pada visual ondel-ondel 3D, diterapkan rekonstruksi visual menggunakan referensi karakter animasi dari Pixar animation studio. Pada bagian gerak dilakukan penerapan 12 prinsip animasi sehingga menghasilkan ilusi kehidupan terhadap ondel-ondel.

\section{SIMPULAN}

Indonesiamemilikikekayaan senitradisional yang unik dan menarik. Hal ini tercipta karena adanya proses akulturasi budaya yang beragam. Melalui percobaan alih media dari konvensional ke digital ondel-ondel Betawi, ditemukan beberapa pendekatan untuk menghasilkan kualitas visual dan gerak yang menghasilkan daya tarik terhadap individu.

Pendekatan yang telah dilakukan dengan menerapkan teori uncanny ke dalam percobaan visual dan gerak terhadap ondel-ondel Betawi digital. Hasil dari percobaan tersebut, secara visual menghasilkan tampilan ondel-ondel yang ikonik berdasarkan pendekatan visual film animasi Pixar. Secara gerak aplikatif ilusi dari kehidupan dengan menerapkan teknik rotoscope animasi dan 12 prinsip animasi dalam menghasilkan gerak dinamis pada ondel-ondel digital. 
Penelitian ini perlu disempurnakan lagi dalam penelitian lanjutan dengan cara membuat data 3D ondel-ondel yang lebih sesuai dengan model aslinya. Kemudian dalam gerak bisa memanfaatkan teknologi yang lebih baru seperti motion capture.

\section{KEPUSTAKAAN}

Andri R.M., L. (2016). SENI Pertunjukan Tradisional di Persimpangan Zaman: Studi Kesenian Menak Koncer Sumowono Semarang. HUMANIKA. https://doi.org/10.14710/ humanika.v23i2.13642

Arshad, M. R., Yoon, K. H., Manaf, A. A. A., \& Ghazali, M. A. M. (2019). Physical rigging procedures based on character type and design in 3D animation. International Journal of Recent Technology and Engineering, 8(3). https://doi.org/10.35940/ijrte.C5484.098319

Ajitec. (2018). “Ondel - Ondel." 2020. https://3dwarehouse.sketchup. c o m / mode $1 / 7$ c 94 e c 0 d - 03 e 7 4 ce 9 - a 141 - 4 ad 97 c c 4 f 1 f0/Onde 1 Ondel?hl=en\&login=true\#.

Bai, Y., Kaufman, D. M., Liu, C. K., \& Popović, J. (2016). Artist-directed dynamics for 2D animation. ACM Transactions on Graphics, 35(4). https://oi. org/10.1145/2897824.2925884

Bouwer, W., \& Human, F. (2017). The Impact of the Uncanny Valley Effect on the Perception of Animated Three-Dimensional Humanlike Characters. The Computer Games Journal, 6(3). https://doi.org/10.1007/s40869-0170041-8

Chienita, I., Susanto, E. H., \& Winduwati, S. (2019). Persepsi Masyarakat Betawi Terhadap Fenomena Ondel-Ondel Ngamen. Koneksi. https://doi.org/10.24912/kn.v2i2.3913

Cohen, M. I. (2014). Wayang Kulit Tradisional dan Pasca-Tradisional di Jawa Masa Kini. Jurnal Kajian Seni. https://doi.org/10.22146/art.5965

Endless reference. (2011). Athletic Male Standard Walk. Retrieved from Video website: https:// www.youtube.com/watch?v=GBkJY86tZRE

Freud, S. (2003). The Uncanny. Canada, USA: Penguin Classics.

Gubernur Provinsi DKI. (2017). Patent No. 11.
Indonesia: Ondel-ondel Ikon Budaya Betawi.

Haqqu, R. (2020). Era Baru Televisi dalam Pandangan Konvergensi Media. Rekam. https://doi.org/10.24821/rekam.v16i1.3721

Harari, Y. N. (2018). Adab untuk Abad ke 21. Manado: Global Indo Kreatif.

Irianto, A. M. (2017). Kesenian Tradisional Sebagai Sarana Strategi Kebudayaan di Tengah Determinasi Teknologi Komunikasi. Nusa: Jurnal Ilmu Bahasa dan Sastra. https://doi. org/10.14710/nusa.12.1.90-100

Jentsch, E. (1906). On the Psychology of the Uncanny ("Zur Psychologie des Unheimlichen", Translated by Roy Sellars, online at: http://www.cpmg.org.br/artigos/ on_the_psychology_of_the_uncanny.pdf). Psychiatrisch-Neurologische Wochenschrift.

Koentjaraningrat.(2007). "Manusia dan Kebudayaan Di Indonesia." In Djambatan. https://doi. org/10.1016/s0044-8486(97)00050-1

Mori, M., MacDorman, K. F., \& Kageki, N. (2012). The Uncanny Valley. IEEE Robotics and Automation Magazine. https://doi. org/10.1109/MRA.2012.2192811

Pixar. (2021). Pixar Style. Retrieved from www. pixar.com

Pollick, F. E. (2010). In search of the uncanny valley. Lecture Notes of the Institute for Computer Sciences, Social-Informatics and Telecommunications Engineering. https://doi. org/10.1007/978-3-642-12630-7_8

Purbasari, M., Marianto, M. D., \& Burhan, M. A. (2019). Ondel-ondel Kekinian: Boneka Besar Betawi di Zaman Modern. Productum: Jurnal Desain Produk (Pengetahuan Dan Perancangan Produk). https://doi. org/10.24821/productum.v3i6.2429

Pixar. (2021). Pixar Style. Retrieved from www. pixar.com

Sultana, N., Meissner, N., \& Peng, F. L. Y. (2013). Exploring Believable Character Animation Based on Principles of Animation and Acting Principles. Proceedings - 2013 International Conference on Informatics and Creative Multimedia, ICICM 2013. https://doi. org/10.1109/ICICM.2013.69 
Tay, S. I., Lee, T. C., Hamid, N. Z. A., \& Ahmad, A. N. A. (2018). An Overview of Industry 4.0: Definition, Components, and Government initiatives. Journal of Advanced Research in Dynamical and Control Systems.

Tri Widadijo, W. (2020). 12 Prinsip Animasi Dalam Serial "Adit \& Sopo Jarwo." AKSA: Jurnal Desain Komunikasi Visual, 1(1). https://doi. org/10.37505/aksa.v1i1.7

Williams, R. (2012). The Animator's Survival Kit: A Manual of Methods, Principles and Formulas for Classical, Computer, Games, Stop Motion and Internet Animators. Farrar Straus \& Giroux.

Wikayanto, A., Grahita, B., \& Darmawan, R. (2019). Unsur-Unsur Budaya Lokal dalam Karya Animasi Indonesia Periode Tahun 2014-2018. REKAM, 15(2). https://doi.org/10.24821/ rekam.v15i2.3003

Xu, T., Chen, M., Xie, M., \& Wu, E. (2011). A Skinning Method in Real-time Skeletal Character Animation. International Journal of Virtual Reality, 10(3). 